\title{
MANAGEMENT OF AGRICULTURAL POST-PRODUCTION RESIDUES FOR ENERGY PRODUCTION IN RURAL AREAS - A CASE STUDY
}

\author{
Maciej NEUGEBAUER, Faculty of Technical Sciences, University of Warmia and Mazury in Olsztyn, ul. Michała Oczapowskiego \\ 2, Olsztyn 10-719, Poland, maciej.neugebauer@uwm.edu.pl_(corresponding author) \\ Janusz GOLASZEWSKI, Faculty of Agriculture and Forestry, University of Warmia and Mazury in Olsztyn, ul. Michała \\ Oczapowskiego 2, Olsztyn 10-719, Poland, janusz.golaszewski@uwm.edu.pl \\ Wojciech MIĄSKOWSKI, Maciej Neugebauer, Faculty of Technical Sciences, University of Warmia and Mazury in Olsztyn, ul. \\ Michała Oczapowskiego 2, Olsztyn 10-719, Poland, wojciech.miąskowski@wmu.edu.pl
}

\begin{abstract}
The paper shows - from the point of view of the need to increase the share of energy obtained from renewable sources, examples of "good energy practices" for four locations. This goal is primarily related to the reduction of climate changes caused by high GHG emissions - but also fits in the "zero waste" strategy in the case of using post-production biomass as an energy source. Examples are described showing four RES installations in operation - two at the farm level and two at the municipal level. The data for the individual installations are summarized. All the described installations are located in north-eastern Poland - in the Warmian-Masurian Voivodeship. Biogas installations in two farms are described - one micro installation and one large. A large installation has a power of $0.999 \mathrm{MWe}$ and $1.1 \mathrm{MWt}$, and a small one $-11 \mathrm{~kW}$ of electric and thermal power. In the case of a large biogas plant, the investment cost for $\mathrm{W}$ is $21 \%$ of the investment cost for a micro biogas plant. Operating costs of biogas plant operation in relation to the installed capacity - micro-scale biogas plants are only $59 \%$ of costs for a large biogas plant. It was shown how a particularly large biogas plant can cooperate with the local community - by distributing heat from cogeneration to the municipal heat network. On the other hand, two municipalities that have invested in ecological heat sources are described. In one case, it is biomass-fired boilers - providing some of the residents of the commune and communal buildings with domestic hot water. and central heating - and in the second - installation of heat pumps to cover the needs of the municipal school. These examples show that it is possible to implement such solutions. At the same time - local communities, which are often opposed to investing in renewable energy source (RES) in their vicinity, should be made aware of what social, energy and general benefits are associated with such solutions. Due to the calculated factor of $0.2 \%$ of biogas installations in relation to the number of potential farms where such installations are possible and justified - the promotion of such "good energy practices" is absolutely necessary.
\end{abstract}

Keywords: biogas, agriculture waste, agriculture post-production residues, renewable energy source

\section{INTRODUCTION}

With the development of technology and the ever-growing world population - and the related increase in consumption, new problems and challenges arise (Kumar, 2020). An example of these problems may be the constantly growing energy crisis - related, inter alia, to the depletion of fossil fuel resources - but also to the growing $\mathrm{CO}_{2}$ emissions - related to their combustion (Brumer 2018). And this, in turn, translates according to research results on increasing climate change (Johnsson et al. 2019). The second area of problems in the modern world - is the problem of waste and post-production residues - which in many parts of the world are treated as garbage - and, as a consequence, are dumped in landfills (Pajdak, Szymanek, 2017).

These problems and challenges are also visible in agricultural production - in particular in the case of intensive agricultural production (Myczko, et al. 2019; Lipiński, et al. 2018). An example may be animal production - e.g. milk in which (compared to previous production methods) the energy consumption per unit of product obtained increases significantly - associated with the need to comply with the still higher standards of milking and milk storage (Fathollahi, et al. 2018).

At the same time, increasing economic pressure - to increase profitability and profits from production by increasing the stocking density - is also increasing the amount of post-production waste, such as manure or slurry (depending on the animal husbandry technology used on the farm) - Martinho (2021).

The amount of waste obtained is often much greater than the potential for field management resulting from good agricultural practices or the nitrogen directive (Kamilaris et al., 2020).

One of the attempts to meet these two challenges and find a reasonable solution is to try to use the resulting waste from agricultural production (not only animal production) for energy purposes (Alatzas, et al. 2019).

Copyright () 2021 The Authors. Published by Vytautas Magnus University. This is an open-access article distributed under the terms of the Creative Commons Attribution License (CC BY 4.0), which permits unrestricted use, distribution, and reproduction in any medium, provided the original author and source are credited. 
On the other hand - according to the "zero waste" strategy - it is by all means beneficial - that the resulting production residues are disposed of as close as possible to the place of their generation (Mannarino, 2021; Zorpas, 2020). It should be remembered that transporting these residues also requires the use of primary energy - contributing to an increase in global $\mathrm{CO}_{2}$ emissions and the demand for fossil fuels (Neugebauer, 2017).

The "zero waste" strategy - does not require production to take place without any waste or residues - but that they should be disposed of with a positive energy balance - from the point of view of waste management itself. The closer to the place of disposal of the generated waste is to the place of its generation, the more favorable this balance is (Katinas, 2019).

Such solutions involving various technologies are studied and described in the world e.g. in the work of Enescu, Diaconi (2018) an example of cogeneration of electricity and heat production for biogas plants in Romania is shown.

In this paper - examples of such solutions are presented - both from the areas of north-eastern Poland. The obtained results were subjected to preliminary energy and economic analyzes, and on this basis, attempts were made to evaluate and generalize such solutions.

The work aims to describe the existing solutions in the field of renewable energy sources at the level of a commune (two cases) and a farm (two cases). Based on the described solutions for investments in biogas plants, a basic economic and energy analysis was made. On its basis, the potential for the development of agricultural biogas plants in Poland was demonstrated.

These analyzes - were made for specific installations - but the results obtained are similar to those for the collective analyzes for the Warmia and Mazury (Igliński, 2017) or Podlaskie (Nikiciuk, 2019) voivodeships.

At the same time - the analyzes performed show great potential for the development of agricultural biogas plants in Poland. Obstacles to their development - this article has not been analyzed - but they are well described in the literature - compare, for example, Gostomczuk (2017) or Ignaciuk, Sulewski (2021). Basic evaluation indicators are the installed capacity of the biogas plant (heat and electricity), investment and operating costs. The technology used - the number of substrates, the method of their acquisition and possible preparation - the quality and quantity of the obtained digestate and the possibilities of its management. These data are the most important for people planning to build a biogas installation on a farm.

\section{INDICATED OBJECT}

As part of the work, in-situ research was performed for four implementations. For two farms - in which there are operating biogas plants that process bio-waste generated on farms into biogas and heat, and two towns - in which municipalities invested in RES to prepare heat for residents and public buildings. All analyzed cases are located in two localities in the Warmińsko-Mazurskie voivodship (north-eastern part of Poland). The preliminary results are described below.

1. A biogas plant as an element in the chain of values in the sustainable production of an agricultural farm.

The biogas plant BIO-NIK ELEKTRA Sp. z o.o. in Kisielice, of the capacity 0.999 MW and 1.1 MW, launched in 2014, is an integral part of an agricultural farm (1800 ha).

The feedstock used in this biogas plant is maize silage in an amount of 17.5 thousand tonnes and slurry in an amount of $7000 \mathrm{~m} 3$ obtained from own arable land and piggery. The biogas plant is a classical installation with sections of harvest, ensiling and storage of maize silage, and the transport of slurry, a fermentation digester and secondary digester, digestate tank, and a cogeneration system of the capacity of 1.2 MW. The average annual production of biogas is 4.300 million m3, including $8400 \mathrm{MWh}$ of electricity and 29.733 GJ of heat. The biogas plant has a potential for further improvement of energy efficiency.

Following the principles of good agricultural practice, digestate from the biogas plant is used for organic fertilisation of the farm's fields. According to the current soil analyses, the systematic enrichment of soil with organic matter from digestate has had a positive effect on the concentration of carbon in soil reaching the level of $2.2 \%$, which indicates a significantly higher content of organic matter in soil compared to the values of 1-2\% for 56\% of arable lands in Poland.

The biogas plant, while generating revenue from electric power sold to an electrical grid, is also the final stage of organic matter circulation and of some of the heat power on the farm, and has a positive impact on the local community as an element of the municipal district heating system.

The added value of the biogas plant operating on the farm has an economic dimension (price for sold kilowatt of electric power, own costs of operating the biogas plant + price for blue certificates), as well as environmental (digestate mass supplied to the farm's fields) and social aspect (quantity and price of heat power sold to the district heating system in Kisielice municipality).

\section{A hybrid system of supplying a district heating network with renewable energy}

The district heating system in the municipality Kisielice was the starting element in building the municipality's energy independence based on renewable energy resources. Low-efficiency and high-emission local boilers were started to be replaced in 2004, when two biomass boilers, with the capacity of 1 and $2 \mathrm{MW}$, were installed. Next, by 2007, the heating plant had been expanded by installing another boiler, with the capacity of $3 \mathrm{MW}$, and a p100 kW photovoltaic power plant. This structure of the heating plant improves the rational operation of the boilers, depending on needs and maintenance of the boilers. Electricity is sold to the electric grid.

The source of biomass is cereal straw, pressed in rectangular bales to the density of $150 \mathrm{~kg} / \mathrm{m}^{3}$, each bale measuring of $80 \times 120 \mathrm{~cm}$ in the cross-section and $200-300 \mathrm{~cm}$ of length. The heating plant, having 40-60 contract agreements with local farmers, gathers straw directly after cereal harvest, from 1,300 ha at the most. The cost of buying straw from a farmer is $50 \mathrm{PLN} / \mathrm{t}(€ 11 / \mathrm{t})$. The total cost incurred to the heat plant, covering the purchase, transport, preparation of straw for storage, is $95 \mathrm{PLN} / \mathrm{t}(€ 21 / \mathrm{t})$. The heating plant can easily acquire sufficient quantities of straw. Straw is transported to 
the heating plant and stored in two heaps under a roof. Biomass is fed with a front loader to a self-propelled telescope loader and then, having been cut with shredders, it is fed to a boiler through a system of belt conveyors, rotary lock and screw feeder. The biomass storehouse, adjacent to the boiler room, has a capacity for storing 240 tonnes of pressed straw. At the average efficiency of the broilers, reaching $90 \%$, the annual average consumption of straw is 3.5 thousand tonnes. The potential use of the ash in even greater than the current use. The ash obtained in the process is collected by local farmers for free, and applied as a fertilizer on their fields. The potential use of ash that is suitable for being managed is even greater than today. Thus, the heating plant corresponds well to the zero strategy of action.

Currently the district heating network is $15.9 \mathrm{~km}$ long. The heat is supplied to residential houses, multi-flat buildings and detached houses, shops, public buildings and health care buildings, in total 260 contracts, including 200 single-family houses. The cost of heat for final user is $13.60 \mathrm{PLN} / \mathrm{kWh}(€ 3 / \mathrm{kWh})$. The total contracted capacity is $2.6 \mathrm{MW}$ (approximately $50 \mathrm{GWh} /$ year), which implicates a potential for the expansion of the number of users. Among the factors that can stimulate the development of the heating network, the following are indicated: improved quality of fuel achieved by investing in roofed storage facilities, and modernisation of district heating substations, including new heat exchangers.

\section{Biogas microplant in an agricultural production system}

A biogas plant processing waste from ongoing agricultural production is a key component of close-circuit bioeconomy.

Thes farm covers 430 ha of agricultural arable land. The farm owner keeps dairy and meat cattle in a close circuit system, including the full production cycle from birth to dairy or meat production. On average, the farm rears 120 calves, 150 dairy cows and 130 meat cattle. Cattle slurry is the only feedstock supplied to an on-farm biogas plant, which is technologically and functionally integrated with the dairy cows' shed. During the technological process, slurry is transported to a mesophilic digester. The biogas produced there $\left(60 \% \mathrm{CH}_{4}\right.$ and $\left.40 \% \mathrm{CO}_{2}\right)$, passing through an air lock, electric valve and carbon filter, feeds two electric engines, each with the power of $11 \mathrm{~kW}$. The heat generated in the engine, water-cooled exhaust manifold and combustion gas heat exchanger are used to heat the digester and produce hot water. Digestate is collected in a tank and used for fertilization of the farm's fields.

\section{Municipal system of energy prosumers}

The municipality of Barciany is one of northern Poland's municipalities lying on the border of Poland and Russia. It is a rural municipality with a relatively low population density rate of 23 people $/ \mathrm{km}^{2}$, and the dominance of farmland ( $83 \%$ of all land) in the land-use structure. Practically, all the municipality's area is covered by the Natura 2000 environmental protection programme., which limits the possibility of constructing large wind and photovoltaic farms.

The municipality of Barciany has been steadily developing its energy independence based on renewable energy resources in the system of the energy producer and consumer (prosumer). In the first stage, in 2009, two municipal biomass-fed district heating plants of the capacity of 1.3 MW and 0.3 MW were created through the natural conversion of municipal boiler plants powered with solid fuels, used until then. The heating plants work during the heating season and supply heat (56 clients) to family farms and public buildings, including the Municipal Office building, a sports hall, schools and the Roads and Green Areas Authority facilities. The fuel used in the heating plant are wooden chips from trimming roadside shrubs and from other sources of waste biomass. The length of the district heating network transmission pipes, including connection pipes to the buildings, is $2,073 \mathrm{~m}$, and the total area heated is 13.5 thousand $\mathrm{m}^{2}$, while the contracted heat energy is around $1,000 \mathrm{~kW}$. The next stage, carried out since 2013, includes the installation of heat pumps powered by electricity from the electricity grid in two municipal schools: two ground source heat pumps of the capacity 100 and $130 \mathrm{~kW}$ (41 vertical boreholes to a depth of $100 \mathrm{~m}$ ) were installed in the Drogosze school, while three heat pumps of the total capacity of $160 \mathrm{~kW}$ (28 vertical boreholes to a depth of $100 \mathrm{~m}$ ) were installed in the school in Mołtajny. As a result, the cost of supplying these schools with heat in the municipal's budget was reduced by $70 \%$. In the next stage, in 2017, a small photovoltaic farm of a capacity of $29 \mathrm{~kW}$ was installed on the premises of the Municipal Office and the municipality's office and workshop building was fitted with a heat pump of the capacity of $57.6 \mathrm{~kW}$ (5 boreholes down to a depth of $200 \mathrm{~m}$ ) and a photovoltaic installation of the capacity of $8.5 \mathrm{~kW}$. The generated electricity is sold to an electricity distributor, with the profits added to the municipality's revenues.

It is the municipality authorities' opinion that the further development of the district heating system in the municipality will be largely dependent on the availability of natural gas from the local gas distribution network currently under construction. The transition from biomass-based fuel to natural gas can entail the need to modernise the present system.

\section{DISCUSSION}

According to the data of the Polish Central Statistical Office (GUS) (2021), there are 118 thousand farms in Poland engaged in milk production and 170 thousand breeding pigs. Against this background - the number of agricultural biogas plants in Poland is frighteningly small - because according to GlobEnergia (11/05/2020), 120 agricultural biogas plants are in operation in Poland. In turn, according to "The register of agricultural biogas producers" as of August 31, 2021 107 entities producing biogas are registered in Poland. As the slurry is the primary substrate most often chosen by producers in biogas plants in Poland (ibid.), This shows the scale of potential installations. Even if we assume that every fourth farm has the potential to install biogas plants for its substrates - our potential is currently used in less than $0.2 \%$.

Increasing the number of agricultural biogas plants in Poland is in everyone's interest. Ammonia and other GHGs released from stored slurry/manure will decrease. The digestate produced in the biogas plant will be easier to apply to crops - at the same time reducing the need to use artificial fertilizers. On the other hand, farms - as shown in the analyzed cases - will become partially energy self-sufficient, regardless of the scale of production and the installed biogas plant (cogeneration systems in biogas plants will enable obtaining heat and electricity). The analysis of the reasons why the 
percentage of agricultural biogas installaions in relation to the potential in Poland is so low exceeds the scope of this report. However, everything should be done - to show farmers and local communities (potential investors, users and possibly beneficiaries) the benefits of building and operating a biogas plant. It should be emphasized both social benefits (lower GHG emissions, lower consumption of primary fuels, increasing the amount of "green" energy obtained in Poland and finally lower environmental risk associated with storage and application to slurry/manure fields.

Such solutions should be promoted - by popularizing the currently available programs - e.g. Agroenergia - which started in July 2021 and is available until December 2021 (or until funds are exhausted).

At the same time - economic analyzes related to investment costs and expected profits show - that farmers should form investment groups - Dach et al. (2021). The same conclusions can be drawn on the basis of the analyzes carried out for the two researched farms. A summary of the obtained data is given in Table 1. On their basis, Fig. 1. Fig. 1a) shows the investment costs in relation to the capacity of the biogas plant. For small (micro) biogas plants - these costs are much lower than for large installations. However, if we relate them to the unit installed capacity in a biogas plant - Fig. 1b) (to total power - thermal and electric), it turns out that in the case of a large biogas plant, the investment cost per $1 \mathrm{~W}$ is only $21 \%$ of the investment cost in a micro biogas plant (of course per $1 \mathrm{~W}$ ). Due to the almost identical thermal and electric power of the analyzed biogas plants (Table 1) - for similar separate analyzes for electric and thermal power, identical results will be obtained. But - analyzing the operating costs (current operation, repairs, power supply, etc.) of the biogas plant in relation to the installed capacity - in this case, the micro biogas plant is more profitable (cheaper to maintain) the operating costs per W installed capacity of the micro-scale biogas plant are only $59 \%$ of the operating costs of a large biogas plant. However, because investment costs are the largest component of costs - creating investment groups by several farmers to build one common biogas plant is economically justified.

Tables 1 . Summary of data for the two analyzed biogas plants (costs were calculated based on the exchange rate $1 €=4.5$ PLN)

\begin{tabular}{|c|c|c|c|c|c|c|c|c|c|}
\hline \multirow{2}{*}{$\begin{array}{l}\text { biogasplant } \\
\text { skale. }\end{array}$} & \multirow{2}{*}{$\begin{array}{l}\text { power of } \\
{[\mathrm{kW}]}\end{array}$} & \multirow[t]{2}{*}{ biogasplant } & \multicolumn{2}{|c|}{ investment costs } & \multirow{2}{*}{$\begin{array}{l}\text { operating } \\
\text { costs } \\
\mathrm{k} €\end{array}$} & \multirow{2}{*}{$\begin{array}{l}\text { investment } \\
\text { power unit } \\
€ / \mathrm{W}\end{array}$} & \multirow{2}{*}{$\begin{array}{l}\text { cost per } \\
\text { PLN/W }\end{array}$} & \multicolumn{2}{|c|}{$\begin{array}{l}\text { operating cost per power } \\
\text { unit }\end{array}$} \\
\hline & & & $\mathrm{k} €$ & kPLN & & & & $€ / \mathrm{W}$ & PLN/W \\
\hline \multirow{3}{*}{ micro } & elektric & 11 & & & & & & & \\
\hline & thermal & 11 & 200.00 & 900.00 & 30.00 & 9.00 & 40.5 & 0.73 & 3.29 \\
\hline & total & 22 & & & & & & & \\
\hline \multirow{3}{*}{ large } & elektric & 999 & & & & & & & \\
\hline & thermal & 1100 & 4000.00 & 18000.00 & 1700.00 & 1.90 & 8.55 & 1.23 & 5.54 \\
\hline & total & 2099 & & & & & & & \\
\hline
\end{tabular}

In practice, as the examples described in chapter 2 show each case should be considered individually. It is necessary to strive for the situation similar to the situation on the PV installation market that installation companies will "select" the best solution (from the point of view of various criteria) in individual cases and possibly advise how large investment groups should arise in order to obtain an economically viable installation in a given case. However what should be emphasized in this case, in the analysis of economic profitability, one should not look only at energy gains but also at the profit (benefit) from the management of slurry (manure and the like) and obtaining a perfect fertilizer, which is digestate completely safe for plants . So this solution is part of the "zero waste" strategy and brings additional profits in the form of less expenditure on fertilizers. As a consequence, the whole solution in the case of the described micro biogas plant despite theoretically unprofitable investment from the energy and economic side, in the entire account of THIS installation is profitable (brings profit).

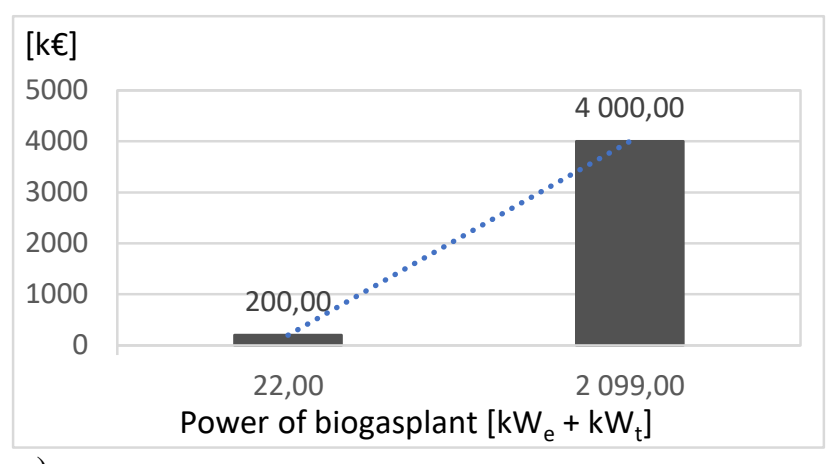

a)

Figure 1. investment costs depending on the size of the biogas plant - a) and per power unit - b)

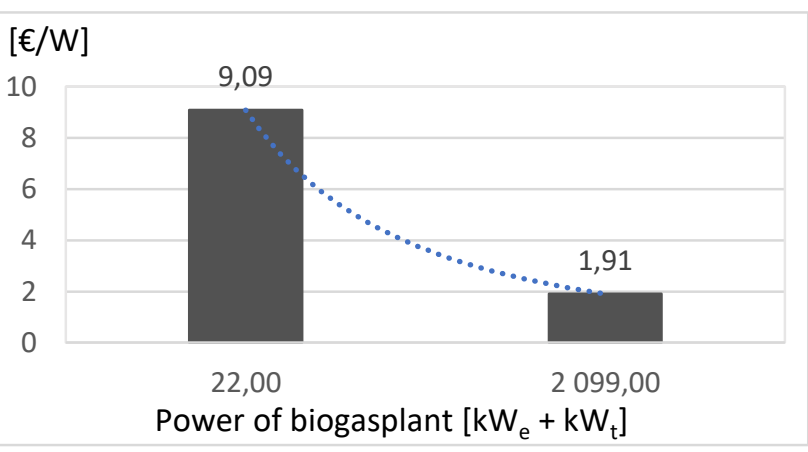

b)
of the biogas plant - a) and per power unit - b)

Equally high potential for the use of RES is at the municipal level - although in this case it is not possible to conduct one joint analysis. In Poland there are (according to the data of the Central Statistical Office) 652 urban-rural communes and 1,523 rural communes. All municipalities - in accordance with the "Energy Law" Act, are required to develop heat, electricity and gas fuel supply plans. Documents are to open the development perspective for at least 15 
years and be updated every three years. Communes are entities that, for their area, should create real energy plans with all entities operating in the field of production and transmission / distribution of energy (heat and electricity) and gaseous fuels, as well as energy and fuel consumers. Most often in communes there is a formal approach consisting in the preparation of the above-mentioned plans to meet statutory requirements. No attention is paid to using their plans for real cooperation with the broadly understood energy sector. Such an approach means that local governments, instead of being the basic partner for the professional power industry in shaping the local energy market, take the role of a petitioner, and the prepared documents fill the shelves of offices and have little to do with the actual planning of the development of the local energy market. However, the cases described in Chapter 2 show that also at the municipal level, pro-ecological solutions are possible and cost-effective to implement. In this case, an extensive promotional campaign should also be carried out, often in conjunction with other programs - e.g. anti-smog measures.

The above-described - "good energy practices" - should be promoted and widely disseminated in order to raise the energy awareness of both ordinary inhabitants of local communities and people managing municipalities.

\section{CONCLUSIONS}

Based on the analyzes and calculations performed, the following conclusions can be drawn (regarding the current situation in Poland):

- Assessment of profitability of an agricultural biogas plant - must be performed individually.

○ In the analyzed cases, it was demonstrated that the investment was much more profitable (almost five times) in relation to the capacity unit installed in a biogas plant for large installations.

- Operating costs per W installed capacity in a biogas plant are lower in a micro biogas plant (1.7 times).

- The main advantage in favor of a biogas plant is the possibility of managing the resulting post-production waste on the farm (manure, slurry, etc.).

- The resulting digestate can be used on the farm as a fertilizer.

- The potential of building agricultural biogas plants in Poland is currently used in $0.2 \%$.

- At the level of municipalities - there is also a very high potential for the use of the resulting organic production residues - for energy purposes. For example, waste biomass after cleaning roadsides - an example of a wood chip heating plant in the Barciany commune.

The implementation of such solutions will help to achieve the intended goals of reducing $\mathrm{CO} 2$ and other GHG emissions by Poland and, at the same time, increase the energy security of local communities. In the entire assessment of the profitability of investments in the energy management of post-production waste in agriculture - the reduction of waste generated in the commune/farm should also be taken into account, which fully corresponds to the "zero waste" strategy and at the same time translates into a reduction in energy consumption for transport and processing of waste generated for the municipality/farm - or in the case of landfilling - lower uncontrolled GHG emissions..

\section{REFERENCES}

1. Alatzas, S., Moustakas K., Malamis D., Vakalis S. 2019. Biomass potential from agricultural waste for energetic utilization in Greece Energies, Vol. 12(6), 1095. https://doi.org/10.3390/en12061095

2. Brummer V. 2018. Community energy-benefits and barriers: A comparative literature review of Community Energy in the UK, Germany and the USA, the benefits it provides for society and the barriers it faces. Renewable and Sustainable Energy Reviews, Vol. 94, pp. 187-196. https://doi.org/10.1016/j.rser.2018.06.013

3. Dach J., Kula D., Woźniak E., 2021, The exploitation of innovative biogas plant by group of farmers. Online International Conference Legal and Economic Perspectives of Energy Cooperatives' Development in Poland and other countries. Conference materials.

4. Enescu A., and E. Diaconu. 2018. Cogeneration plant on biomass-case study. Scientific Bulletin of the Electrical Engineering Faculty, Vol. 18, pp. 7-11. https://doi.org/10.1515/sbeef-2017-0027

5. Fathollahi H., Mousavi-Avval S. H., Akram A., Rafiee S. 2018. Comparative energy, economic and environmental analyses of forage production systems for dairy farming. Journal of Cleaner Production, Vol. 182, 1 pp. $852-862$. https://doi.org/10.1016/j.jclepro.2018.02.073

6. Johnsson F., Kjärstad J., Rootzén J. 2019. The threat to climate change mitigation posed by the abundance of fossil fuels. Climate Policy, Vol. 19(2), pp. 258-274. https://doi.org/10.1080/14693062.2018.1483885

7. GlobEnergia, 2020.05.11, Przyszłość Biogazu w Polsce. On-line: https://globenergia.pl/przyszlosc-biogazu-w-polsce/ access: 03.09.2021.

8. Gostomczyk W. 2017. Stan i perspektywy rozwoju rynku biogazu w UE i Polsce-ujęcie ekonomiczne. Problemy Rolnictwa Światowego, Vol. 17(2). https://doi.org/10.22630/PRS.2017.17.2.26 (In Polish)

9. GUS (Główny Urząd Stataystyczny), 2021, Powszechny Spis Rolny 2020. Raport z wyników. On-line: https://stat.gov.pl/obszarytematyczne/rolnictwo-lesnictwo/psr-2020/powszechny-spis-rolny-2020-raport-z-wynikow,4,1.html access: 03.09.2021. (In Polish)

10. Igliński B.; Buczkowski R. 2017. Potencjał Techniczny i Możliwości Wykorzystania Biogazu Utylizacyjnego na Przykładzie Województwa Warmińsko-Mazurskiego. Rynek Energii, Vol. 4, pp. 56-62. 
11. Ignaciuk W., Sulewski P. 2021. Conditions of Development of the Agricultural Biogas Industry in Poland in the Context of Historical Experiences and Challenges of the European Green Deal. Zagadnienia Ekonomiki Rolnej, Vol. 368(3), pp. 55-77. https://doi.org/10.30858/zer/140413

12. Kamilaris A., Engelbrecht A., Pitsillides A., Prenafeta-Boldú F. X. 2020. Transfer of manure as fertilizer from livestock farms to crop fields: The case of Catalonia. Computers and Electronics in Agriculture, Vol. $175,105550$. https://doi.org/10.1016/j.compag.2020.105550

13. Katinas V., Marčiukaitis M., Perednis E., Dzenajavičienè E. F. 2019. Analysis of biodegradable waste use for energy generation in Lithuania. Renewable and Sustainable Energy Reviews, Vol. 101, pp. 559-567. https://doi.org/10.1016/j.rser.2018.11.022

14. Kumar M. 2020. Growing population and their environmental impacts in India. International Journal Of Multidisciplinary Education, Vol 10 (1), pp 49-53.

15. Lipiński,. A. J., Lipiński S., Kowalkowski P. 2018. Utilization of post-production waste from fruit processing for energetic purposes: analysis of Polish potential and case study. Journal of Material Cycles and Waste Management, Vol. 20(3), pp. 18781883. https://doi.org/10.1007/s10163-018-0729-2

16. Mannarino M. 2021. The (Almost) Zero-Waste Guide: 100+ Tips for Reducing Your Waste Without Changing Your Life. Tiller Press.

17. Martinho V. J. P. D. 2021. Energy Costs and Farm Characteristics in the European Union: Highlighting Linkages with Structural and Policy Dimensions. Springer Nature. https://doi.org/10.1007/978-3-030-75839-4

18. Myczko A., Sawiński R., Wrzesińska-Jędrusiak E., Aleszczyk Ł., Łaska-Zieja B. 2019. Prosumer biogas installations for the sanitation of slurry and post-production residues from agricultural. Woda Środowisko Obszary Wiejskie, Vol. 19(65), pp. 19-36.

19. Neugebauer M. 2017. The Impact of a biological waste collection strategy on total greenhouse gas emissions in north-eastern Poland. In: 17th International Multidisciplinary Scientific Geoconference SGEM 2017. Modern Energy and Power Sources: Conference proceedings, Vol. 17(43), pp. 91-98. https://doi.org/10.5593/sgem2017H/43/S18.012

20. Nikiciuk M. 2019. Potencjał ekologiczny i prowzrostowy sektora biogazowni rolniczych w województwie podlaskim. In Współczesne problemy ekonomiczne w badaniach młodych naukowców. T. 3, Analizy makro-i mezoekonomiczne, pp. 98-117. Polskie Towarzystwo Ekonomiczne. Oddział. (In Polish) https://doi.org/10.15290/wpewbmn3.2019.08

21. Pajdak A., Szymanek A. 2017. The characteristics and the concept of the utilisation of post-production calcareous waste deposited in landfills. Mineralogia, Vol. 48, pp. 167-179. https://doi.org/10.1515/mipo-2017-0019

22. Zorpas A. A. 2020. Strategy development in the framework of waste management. Science of the total environment, Vol. 716 , 137088. https://doi.org/10.1016/j.scitotenv.2020.137088 